\title{
Combat Against Trafficking in Narcotic Drugs, Psychotropic Substances and Precursors in Kazakhstan
}

\author{
Svetlana Malikovna Baimoldina ${ }^{1}$, Balausa Amanovna Berdimbetovna ${ }^{1} \&$ Shynarbek Kairbekuly Akchabaiev $^{1}$ \\ ${ }^{1}$ L. N. Gumilyov Eurasian National University, Faculty of Law, Astana, Republic of Kazakhstan \\ Correspondence: Svetlana Malikovna Baimoldina, L. N. Gumilyov Eurasian National University, Satpayev str. 2 , \\ Astana, 010000, Kazakhstan. Tel: 8-777-212-8749. E-mail: baimoldinasveta@yandex.ru
}

\author{
Received: March 11, 2015 Accepted: March 31, 2015 Online Published: May 14, 2015 \\ doi:10.5539/res.v7n7p187 URL: http://dx.doi.org/10.5539/res.v7n7p187
}

\begin{abstract}
The article describes the theoretical, legal, and criminological issues of international cooperation of Kazakhstan, national models of some countries in the combat against drug trafficking, and the spread of drug use. The authors disclosed the basic concepts of structural elements of the mechanism for legal regulation of the combat against illicit trafficking in narcotic drugs, psychotropic substances and precursors in Kazakhstan, carried out the analysis of modern criminal and common law in terms of regulation of the methods of combating against illicit trafficking in narcotic drugs, psychotropic substances and precursors and related compounds of these types of crime, criminological characteristics of drug-related crimes across regions and areas of Kazakhstan. The result of the scientific research is the formulated theoretical propositions and recommendations for improving the current legislation of the Republic of Kazakhstan and its practical application.
\end{abstract}

Keywords: narcotransit, drug gangs, UN, the Criminal Code, international criminal groups

\section{Introduction}

The urgency of combating against illicit trafficking in narcotic drugs, psychotropic substances, and precursors is extremely high, as non-medical use of these substances causes irreparable harm to human health, especially to the younger generation. Today, among the urgent problems facing the Kazakhstani society, the problem of drug abuse and drug trafficking can be highlighted, as a global threat to public health and national security. In this regard, the President of the Republic of Kazakhstan, N. A. Nazarbaiev defines the combat against drug abuse and drug trafficking as one of the top priorities (Nazarbaiev, 2014).

Given its prevalence and causes damage, the international community applies concerted efforts to combat against it. For the following purpose, the corresponding legal base was established, including the accepted Memorandum (1996) on mutual assistance and cooperation in the combat against drug production, trafficking, abuse of narcotic drugs, psychotropic substances and precursors in Central Asia as of May 04, 1996 and others (Memorandum, 1996).

In accordance with the Constitution of the Republic of Kazakhstan (Constitution, 2009), the Law of the Republic of Kazakhstan as of July 10, 1998 "On narcotic drugs, psychotropic substances, precursors and measures to combat against illicit trafficking and abuse" (the Law, 2014) and other normative legal acts of the Republic Kazakhstan regulating traffic in narcotic drugs, as well as with international treaties ratified by the Republic of Kazakhstan, the rules for the State control of narcotic drugs, psychotropic substances and precursors in the Republic of Kazakhstan were developed (the Resolution 2007). The President's Message to the people of Kazakhstan (2030) indicates the need to tighten liability for the importation and distribution of drugs due to the increase of public danger of their trafficking for the society (the Message, 2007).

Currently, in many CIS countries, there is an increase in crimes related to drug trafficking: in the Russian Federation, over the past ten years the number of drug-related crimes has increased more than 10 times, from 1995 to the present time, the number of analysed crimes in Georgia increased by $8 \%$, in Ukraine by $12 \%$, in Kyrgyzstan-31\%, and in Kazakhstan-59\%. Double increase was observed in Belarus and Tajikistan. The highest growth of these crimes occurred in Moldova - almost four times (Zhumabaiev, 2002).

On July 10, 1998, Kazakhstan adopted the Law "On narcotic drugs, psychotropic substances, precursors, and measures to combat against illicit trafficking and abuse". The current stage of the struggle with narcotisation of 
the population in Kazakhstan is associated with a number of important initiatives of the President, having not only domestic but also international significance. Due to this, the Ministry of Interior of Kazakhstan managed to achieve the necessary balance and consistency of the ongoing anti-drug measures, which was reflected in the form of specific activities in the strategy to combat against drug addiction and drug trafficking in the Republic of Kazakhstan for 2006-2014 (the Decree, 2006-2014), policy documents of the Government adopted for its execution.

\section{Literature Review}

The problems related to the prevention of crime in the illicit trafficking in narcotic drugs were covered in the writings of scholars of various disciplines and are found in studies of domestic and foreign scholars from different periods. The scientific research by M. Ansel, Ch. Beccaria, G. Gegel, I. Kant, F. Liszt, S. Montesquieu, A. Prince, A. Feuerbach, E. Ferry, I. Fichte, and other scholars formed the theoretical basis for this study. A significant contribution to the review of the criminal law and other aspects of drug-related crimes, narcotism, and drug addiction was made by the scholars of the Tsarist Russia: L. Antsiferov, I. Levitov, N. Sergeievskiy, V. Spasovich, N. Tagantsev, and others.

Currently, various aspects of combating against drug-related crime, narcotism, and drug addiction in the CIS and Kazakhstan were covered by such scholars as N. M. Abdirov, R. O. Avakyan, Yu. M. Antonyan, A. G. Aliokhin, T. A. Bogolyubova, G. V. Dashkov, A. I. Dolgova, V. M. Yegorshin, A. I. Gurov, E. G. Gasanov, R. N. Gottlieb, D. P. Dzhanashiya, I. N. Druzhinin, V. A. Zhabskiy, A. E. Zhalinskiy, Z. S. Zaripov, V. M. Yesipov, S. M. Inshakov, L. V. Inogamova-Khegai, D. D. Kazharskiy, V. S. Komissarov, V. N. Kurchenko, G. A. Levitskiy, G. M. Meretukov, G. M. Minkovskiy, N. A. Miroshnichenko, A. A. Muzyka, E. N. Nurgaliyeva, V. I. Omigov, K. M. Osmonaliyev, E. F. Pobegailo, M. L. Prokhorova, L. M. Romanova, A. A. Majorov, V. B. Malinin, P. N. Sbirunov, K. R. Sarykulov, A. A. Smagulov, N. A. Sartayeva, K. A. Tolpekin, V. I. Tkachenko and other legal scholars.

The problem of the combat against narcotism was discussed in the number of dissertation researches by legal scholars, sociologists, doctors, and others. Among legal scholars from different countries, the following dissertation researches on the combat against narcotism in all its manifestations shall be mentioned.

For example, Klimenko (2008) revealed the theoretical and practical problems of combating against drug-related crimes, narcotism, and drug addiction in the Russian Federation. The scientific works by Shestakov (1996) disclose criminological characteristics and prevention of crimes committed by the members of youth gangs in their communities: Shestakov (1996) discussed the international legal aspects of non-governmental organizations associated with the United Nations: Demidov (2002) in his studies affected the socio-legal and criminological problems of combat against narcotism.

Abdirov (1999) conducted a comprehensive criminological and criminal legal research of the conceptual problems of combat against narcotism in the Republic of Kazakhstan. Gasanov (2000) focused on criminal law and criminological problems of combating against drug-related crimes in Azerbaijan. The peculiarities of the application of criminal law measures for the prevention and suppression of illicit drug trafficking in the Kyrgyz Republic were disclosed by Osmonaliev (1997). The peculiarities of criminal law and criminal actions against narcotism in the Republic of Yemen and Saudi Arabia were investigated by Masaba Ali Saeed (2000).

The paper by Meretukov (1995) researches legal and criminological problems of the combat against drug trafficking, committed by organized criminal groups: Criminological characteristics and prevention of crimes committed by minors to purchase drugs were highlighted in the dissertation by Orlov (1991). Legal and criminological problems of social rehabilitation of chronic alcoholics and drug addicts have been disclosed in the studies by Grishko (1993).

Sociological aspects of drug-related crimes among young people are covered by Valkova (2012) in the dissertation researches on the following topics: Narcotism among young people: sociological analysis and others.

\section{Materials and Methods}

\subsection{The Methodology of the Scientific Research}

The methodological basis of this research is as follows: general dialectical method of learning general laws and categories of nature, society and the state; general scientific methods - analysis and synthesis, deduction and induction, historical and logical; specific scientific methods - system analysis, logic, comparative, statistical and other types of analysis.

The empirical base of scientific work consists of data collected by the authors in the research process while working in the legal profession, using the method of expert assessments in relation to the object of study; and in 
the study of the court practice for the cases of this category.

The theoretical basis for the study is represented by the research papers on criminal law, criminology, and the general theory of law, philosophy, criminal proceedings, sociology, medicine, psychology, and other branches of science.

\subsection{Criminal Liability for Crimes Related to Trafficking Narcotic Drugs and Psychotropic Substances in the Republic of Kazakhstan}

The regulatory framework of the paper is in the international legal instruments to combat against drug trafficking, the provisions of the Constitution of the Republic of Kazakhstan, the Criminal Code of the Republic of Kazakhstan, the modern criminal law on combating against narcotism and drug trafficking

The Criminal Code of Kazakhstan provides criminal liability for trafficking in narcotic drugs, psychotropic substances and precursors, which occurs in accordance with Art. 259 "Illegal manufacture, processing, purchase, storage, transport, transfer or sale of narcotic drugs or psychotropic substances", Art. 260 "Theft or extortion of narcotic drugs or psychotropic substances", Art. 261 "Habitual use of narcotic drugs or psychotropic substances", Art. 262 "Illicit cultivation of illicit crop plants containing narcotic substances", Art. 263 "Illicit trafficking in toxic substances, as well as materials, tools or equipment used for the manufacture or processing of narcotic drugs, psychotropic or toxic substances", Art. 264 "Organization or maintenance of premises for consumption of narcotic drugs or psychotropic substances, or the provision of facilities for the same purpose", and criminal liability occurs in case of trafficking in narcotic and psychotropic substances and precursors (the Criminal Code of the RK, 2014).

\section{Results and Discussion}

\subsection{Peculiarities of Drug-Related Crimes according to Areas and Regions of Kazakhstan}

A special place in the protection of human rights belongs to the legal state policy aimed at improving law enforcement, combating against the illicit proliferation of trafficking in narcotic drugs, psychotropic or toxic substances, precursors, and persons who use them. In 2014, according to the statistics of the General Prosecutor of the Republic of Kazakhstan (GPRK), the number of reported crimes for "Illegal manufacture, processing, purchase, storage, transportation, transfer or sale of narcotic drugs or psychotropic substances" (Article 259 of the Criminal Code of the RK) reached 35, the number of crimes for "Illicit cultivation of illicit crop plants containing narcotic substances (Art. 262) reached 80, the number of crimes for "Illegal medical and pharmaceutical activity and illegal issuance or forgery of prescriptions or other documents that give the right to obtain narcotic drugs or psychotropic substances" (Article 266) reached 7. Many types of such crimes are not registered due to their high latency and complexity of detection.

Pursuant to the Order of the Chairman of the Committee on Legal Statistics and Special Records of GPRK No. $112 \mathrm{o} / \mathrm{d}$ as of October 26, 2009, the Office for analysis and legal regulation of the Committee analysed the statistical data on the state of the combat against crimes and offenses related to trafficking in narcotic drugs and psychotropic substances and precursors in Kazakhstan in 2009.

The analysis of the statistics shows that the incipient in 2008 recession of drug-related crimes in the country by $4.2 \%$ continued in 2009 , reaching $3.6 \%$. The drug-abuse situation in Kazakhstan is characterized by the following:

- A decrease in the number of reported drug-related crimes;

- An increase in the number of reported crimes related to sales;

- A decrease in the smuggling of narcotic drugs and psychotropic substances;

- A decrease in the number of drug-addicted persons;

- An increase in the number of crimes committed on the grounds of drug use among women and minors;

- Preservation of growth of psychotropic substances consumptions.

In 2009, law enforcement authorities in Kazakhstan registered 9705 drug-related crimes, and in 2008 (10065).

In 2008, the highest number of drug-related crimes was registered in Karaganda (1263), East Kazakhstan (1001) and Kostanai (743) regions, as well as in Almaty (1051) and the South Eastern region (675).

High rates of growth are observed in Kostanai region-11.6\%, as well as Akmola, Kyzylorda and Atyrau regions - more than 10\%, against the background of population decline in Kostanai (3 thousands) and Akmola (3.9 thousands) regions that is evidence of worsening of drug situation in these regions. 
The number of population affects the dynamics of drug-related crimes: despite significant growth in the republic population in 2009 in South Kazakhstan region (44 thousands) and Almaty (24 thousands), the number of reported crimes in this category decreased by $0.2 \%$ and $7.8 \%$, respectively.

According to the Agency on Statistics of the RK, as of December 1, 2009, the number of population amounted to 15 million 981.9 ths people, and the relative share of the number of registered drug-related crimes in the country amounted to 6 crimes per 10 thousands of population. The maximum rates were established in Karaganda (9 crimes) and Kostanai (8) regions.

In total, during the analysed period, there were registered 9230 crimes, which is $2.8 \%$ less than in 2008 (9495). The relative share of the total number of recorded crimes in this category amounted to $95.1 \%(94.4 \%)$. The remaining 4.9\% fall on the Art. 250, 260-265 of the Criminal Code and Part 5 of Article. 266 of the Criminal Code of the RK.

There was an increase of up to 2616 (by 17\%) in crimes associated with the sale or the purpose of sale of narcotic drugs (2235-in 2008). The reported number of crimes related to illegal acquisition, transportation or storage of drugs without intent to sell (part 1 of Article 259 of the Criminal Code of the RK) was less by $8 \%$ (from 4654 to 4283) (Office of GPRK, 2015).

\subsection{Characteristics of Drug-Related Crimes Committed in Organized Forms of Complicity}

One of the critical problems in the organization of an effective combat against spread of drugs in the country is the combat against organized forms of drug-related crimes and drug trafficking. Earlier we discussed activities of organized criminal groups in illicit trafficking of drugs, psychotropic substances, and precursors in the Republic of Kazakhstan (Baimoldina, 2009).

In 2009, the work of law enforcement bodies of the country in this direction considerably strengthened. Thus, we observe $53.5 \%$ increase in the number of completed cases on crimes committed by a group of persons. The strong rates were achieved in the following regions: Aktobe, where the number of completed cases has increased 10 times, Kyzylorda - almost 4 times increase, Almaty - 3 times increase and Pavlodar-more than 2 times increase, and in the city of Astana-3 times increase. 75.4\% increase was observed in the number of cases of crimes committed by an organized group or a criminal community. The wave of drug-related crimes has moved into the western regions of the country: 10 times increase in the number of reported crimes in this category committed by a group of persons, in the Aktobe region, and 2 times increase in West Kazakhstan region.

Such dynamics is caused by attempts of transnational criminal groups to expand drug trafficking in the direction of Afghanistan-Uzbekistan-Kazakhstan-Russia and other countries in Asia, which is a disturbing factor, requiring special attention from law enforcement bodies of our country. Only 4 regions have a registered growth of the named index: Almaty-2 times (per 1 crime), Zhambyl-by $30.6 \%$, Pavlodar-by $25 \%$ and North Kazakhstan - by $20 \%$. At the same time, $51.7 \%$ reduction was observed in the volume of seized drugs received smuggled (from $671.9 \mathrm{~kg}$-in 2008 to $324.4 \mathrm{~kg}$.

These dynamics affected the amount of narcotic drugs and psychotropic substances withdrawn from illicit trafficking. In 2009, their number decreased by $0.1 \%$. In the structure of seized narcotic drugs and psychotropic substances, the highest percentage belongs to cannabis group- $94.2 \%$ or $26 \mathrm{t} 331.5 \mathrm{~kg}$ (in $2008-92.2 \%$ or $25 \mathrm{t}$ $656.5 \mathrm{~kg})$.

Table 1. The ratio of narcotic drugs and psychotropic substances seized in 2009 compared with 2008

\begin{tabular}{lllll}
\hline \multirow{2}{*}{ Name of the narcotic drugs } & \multicolumn{2}{c}{$\mathbf{2 0 0 8}$} & \multicolumn{2}{c}{$\mathbf{2 0 0 9}$} \\
\cline { 2 - 5 } & $\begin{array}{l}\text { total weight } \\
(\mathbf{k g})\end{array}$ & specific weight & $\begin{array}{l}\text { total weight } \\
(\mathbf{k g})\end{array}$ & specific weight \\
\hline Marijuana (cannabis) & $25,656.5$ & $92.2 \%$ & $26,331.5$ & $94.7 \%$ \\
Opium & 16.7 & $0.1 \%$ & 171.9 & $0.6 \%$ \\
Heroin & $1,639.3$ & $5.9 \%$ & 731.6 & $2.6 \%$ \\
Hashish, anasha & 511.1 & $1.8 \%$ & 556.9 & $2.0 \%$ \\
\hline
\end{tabular}


In 2009, law enforcement bodies in Kazakhstan seized 27 tons $954.4 \mathrm{~kg}$ of narcotic drugs and psychotropic substances, including:

- By internal affairs bodies - $22 \mathrm{t} 946.3 \mathrm{~kg}$, including $123 \mathrm{~kg}$ of heroin;

- By national security agencies - 4 t $256.8 \mathrm{~kg}$, including $503.7 \mathrm{~kg}$ of heroin;

- By customs control bodies- $736.8 \mathrm{~kg}$, including $105 \mathrm{~kg}$ of heroin.

The largest volume of heroin was found by the national security agencies. The results of the carried out analysis are directed into the machine of the Attorney General, Department of the Interior, the National Security Committee, the Committee of Customs control of MF of RK, Centre for Forensic Expertise of MJ of RK and territorial bodies of the Committee for the work (Office of GPRK, 2015).

\subsection{International Experience in Combating Against Drug-Related Crimes}

The death penalty for drug offenses is stipulated in the criminal law of Saudi Arabia, the United Arab Emirates, the Republic of Iran, Pakistan, Singapore, and other countries of the world (Mukanov, 2008). Intermediate model of combat is mainly used in countries undergoing the process of transition from a group of producing countries to countries, which use drugs. These are Thailand, India, Turkey, as well as the number includes the countries of the growing consumption-Sweden, Canada, Australia (Mukanov, 2008; Uspanov, 2003).

Improper use of narcotic drugs for medical purposes, resulting in the death of the patient, is punishable by criminal law in Germany (Stage, 2015).

Special regulations are applied to health professionals who are authorized by virtue of their official duties to appoint narcotic drugs for medical purposes. "If the doctor on the basis of medical evidence prescribes drugs to a patient and the patient dies, the question about the criminal acts of the doctor shall emerge. The fact that the patient received the drug on their own, in principle does not preclude criminal liability in accordance with $\$ 222$ of the Criminal Law of Germany (FRG CL) (Golovnenkov 2012; BGH, BeckRS, 2014). Paragraph 222 of FRG CL establishes criminal liability for causing death by negligence, and provides punishment by imprisonment for a term not exceeding five years or a fine" (Golovnenkov, 2012; Stage, 2015).

"Universal jurisdiction (the principle of universality) is a type of jurisdiction in international law (along with the territorial principle, the principle of citizenship, the principle of nationality of the victim and the principle of protection), which determines the competence of the states to bring a person to justice" (Kmak, 2015).

"For the first time, Finland recognized the right to exercise jurisdiction in respect of "international crime" in the Criminal Code in 1996. The Code is a solid basis for such competence. According to Chapter 1, Section 7 of the Criminal Code, the Finnish courts may exercise this jurisdiction over the following offenses: genocide, war crimes, crimes against humanity, severe breaches of the Geneva Conventions, tortures, terrorism, falsification, offenses related to drug trafficking, hijacking and aircraft sabotage, hostage-taking, attacks on internationally protected persons, illegal possession and use of nuclear material, use of chemical weapons, piracy and other unlawful acts against the safety of maritime navigation, etc." (Finnish Criminal Code, 2014).

The studies by American scientists show that investing in the combat against drug trafficking does not only give the necessary impact, but cannot even stop the negative dynamics of the spread of drugs and drug addiction (Criminology, 2003).

According to UN experts, the critical mass of the population of narcotisation in any state, which is followed by the complete degradation of the population, comprises 5\% (Maltsev, 2009).

The combat against these crimes requires the use of effective methods of investigation (Geldibaev, Kosarev, 2014).

\section{Conclusion}

Studies and in-depth analysis of the criminal law and criminological situation in the field of crimes related to drug-related crimes in the Republic of Kazakhstan indicate that the measures used to combat drug-related crimes are not effective enough.

In order to improve the combat against drug trafficking, it is necessary to develop a set of measures aimed at strengthening the combat against crimes related to illegal use of drugs, in accordance with international legal norms in this area, namely:

1) Suppression of transit, development of technologies for synthetic drugs, psychotropic substances, and precursors; 
2) A focus on efforts on drug combat policy to suppress drug usage;

3) Creating the "early warning" and monitoring system for the drug situation on the interstate and international level;

4) Link the combat against drugs with anti-alcohol and anti-tobacco campaigns.

Effective management of activities of the internal affairs bodies in the field of criminology protection at risk from narcotisation, based on continuous monitoring of the drug situation, requires the allocation of tasks and functions aimed at the protection of criminological risk and creating obstacles to the spread of drugs, from the totality of the tasks and functions of the internal affairs bodies and their consolidation in the departmental normative legal act (Voronin, 2010).

Countering drug abuse and drug trafficking in Kazakhstan shall also be carried out in the following areas:

- Modernization of existing legislation;

- Organization of an effective prevention system;

- Cutting off channels of illegal income, production, theft and trafficking of drugs;

- Subsequent development of international cooperation in combating illicit trafficking in narcotic drugs and psychotropic substances;

- Study and use of foreign experience.

\section{Acknowledgements}

The authors express their gratitude to the distinguished legal scholars of the Russian Federation: Doctor of Law, Professor Vladimir Sergeievich Komissarov, Head of the Department of Criminal Law, Moscow State University n.a. M. S. Lomonosov: Honoured Scientist of the Russian Federation, Doctor of Law, Professor Rarog Alexei Ivanovich, Head of the Department of Criminal Law of MSLA n.a. O. E. Kutafin for the organization of conferences on topical issues of criminal law and the provision of conference materials.

\section{References}

Abdirov, N. M. (1999). Conceptual problems of combat against narcotism in the Republic of Kazakhstan: Criminological and criminal-legal research. Abstract of dissertation for the degree of the Doctor of Laws ( $\mathrm{p}$. 54) Almaty.

Baymoldina, S. M. (2008). Drug related crimes as a social phenomenon. The law and the state, 39(2), 145-149.

Baymoldina, S. M. (2009). Activities of organized criminal groups in illicit trafficking of drugs, psychotropic substances and precursors in the Republic of Kazakhstan. In N. A. Lopashenko (Ed.), Criminal policy, criminal law and criminological problems of combat against modern crime and corruption Collection of scientific works (p. 380). Saratov, Saratov Centre for the Study of Organized Crime and Corruption: Satellite, OOO.

BGH, BeckRS. (2014). On other corpus delicti of criminal offenses that may have been committed. BGH, BeckRS 2014, 0357 and Lang, Betaubungsmittelstrafrecht-dogmatische Inkonsistenzen und Verfassungsfriktionen, 2011, 93.

Demidov, I. V. (2002). Socio-legal and criminological problems of combat against narcotism. Abstract of dissertation for the degree of the Candidate of Doctor of Laws. Ryazan.

Finnish Criminal Code. (2014). Finnish Criminal Code 39/1889, last amended 18 September 2014.

Gasanov, E. G. O. (2000). Criminal law and criminological problems of combating against drugs-related crimes (Anti-narcotism). In Abstract of dissertation for the degree of the Doctor of Laws (p. 45). Scientific-Research Institute for Law and Order of the General Prosecutor of the Russian Federation.

Geldibaiev, M. Kh., \& Kosarev, S. Yu. (2014). Qualifications and investigation of drug trafficking crimes (p. 12). $\mathrm{SPb}$ : Publishing House "Yuridicheskiy Tsentr".

Golovnenkov, P. V. (2012). The Criminal Law of the Federal Republic of Germany (2nd ed.). [StGB] research and practical commentary and translation of the text of the Law.

Grishko, A. Ya. (1993). Legal and criminological problems of social rehabilitation. Abstract of dissertation for the degree of the Doctor of Laws (p. 39). Moscow.

Klimenko, T. M. (2008). Problems of combating against drug-related crimes, narcotism and drug addiction in the Russian Federation (the questions of theory and practice). Abstract of dissertation for the degree of the 
Doctor of Laws. Volgograd.

Kmak, M. (2015). The problems of internal application of the universal jurisdiction principle-The case of Francois Bazaramba. Criminal law: The development strategy in XXI century: Materials of the XII International scientific and practical conference (29-30 January 2015, pp. 486-491). Moscow: RG-Press.

Maltsev, Yu. A. (2009). Actual problems of countering the drug threat from Afghanistan (p. 94). SCO activity to counter new threats and challenges in the field of regional security: Proceedings of the research-to-practice conference. Moscow, Izvestiya.

Management of analysis and legal regulation of the Committee on Legal Statistics and Special Records of the General Prosecutor's Office of the Republic of Kazakhstan. (2015).

Masab, A. S. (2000). Criminal law and criminological measures to combat against narcotism in the Republic of Yemen and Saudi Arabia: Abstract of dissertation for the degree of the Candidate of Doctor of Laws. In Ministry of Justice of the Russian Federation (p. 24). Ryazan University of Law and Economics. Ryazan.

Meretukov, G. M. (1995). Legal and criminological problems of the combat against drug trafficking, committed by organized criminal groups: Abstract of dissertation for the degree of the Doctor of Laws. (p. 66).

Mukanov, R. Zh. (2008). Combating drug trafficking in the context of the doctrine of social and legal control over crimes. Almaty.

Nazarbaiev, N. A. (1997). Message from the President to the people of Kazakhstan "Kazakhstan-2030. Prosperity, security and the welfare of all people of Kazakhstan” as of October 10, 1997.

Nazarbaiev, N. A. (2014). The Way of Kazakhstan-2050: Common goal, common interests, common future. Message from the President to the people of Kazakhstan. Astana.

Orlova, A. A. (1991). Criminological characteristics and prevention of crimes committed by minors to purchase drugs. Abstract of dissertation for the degree of the Candidate of Doctor of Laws. M.

Osmonaliev, K. M. (1997). Criminal law measures to prevent and suppress illicit traffickin of narcotic drugs (based on the Kyrgyz Republic materials) (p. 19). dissertation for the degree of the Candidate of Laws.

Ospanova, G. S. (2003). Interaction as a mandatory element of the methodology for the investigation of drug trafficking. Almaty.

Sheli, J. F. (Ed.). (2003). Criminology (Trans. from English ) (p. 617). SPb.: Piter.

Shestakov, D. Yu. (1996). International legal aspects of non-governmental organizations associated with the United Nations: Abstract of dissertation for the degree of the Candidate of Doctor of Laws. (P. 18).

Shestakov, S. V. (1996). Criminological characteristics and prevention of crimes committed by the members of youth gangs in their communities: Abstract of dissertation for the degree of the Candidate of Doctor of Laws. (p.24).

Stage, D. (2015). Criminal legal objective imputation of doctor's prescription of drugs, resulting in the death of a patient in accordance with the German criminal law (pp. 57-570). Criminal law: The development strategy in XXI century: Materials of the XII International scientific and practical conference (29-30 January 2015). Moscow: RG-Press.

The Constitution of the Republic of Kazakhstan (p. 15). (2009). Almaty, Yurist.

The Criminal Code of the Republic of Kazakhstan (as of January 01, 1998 to January 01, 2015)

The Law (2014). The Law of the Republic of Kazakhstan "On narcotic drugs, psychotropic substances, precursors and measures to combat against their illicit trafficking and abuse (as amended as of Dec 29, 2014). Adilet the database of regulations.

Uspanov, Zh. T. (2003). Interaction of the Internal Affairs bodies of the CIS countries in the combat against drug trafficking (special investigative techniques) (p. 320). Almaty.

Valkova, U. V. (2012). Narcotism among young people: a sociology analysis. Abstract of dissertation for the degree of the Candidate of Doctor of Sociology Sciences. Moscow.

Voronin, M. Yu. (2010). Criminological policies to protect the public from narcotisation. Abstract of dissertation for the degree of the Doctor of Laws. Moscow.

Zhumabaiev, E. Zh. (2002). Problems of combating drug trafficking in the Republic of Kazakhstan. Lawyer, 3, 5-6. 


\section{Copyrights}

Copyright for this article is retained by the author(s), with first publication rights granted to the journal.

This is an open-access article distributed under the terms and conditions of the Creative Commons Attribution license (http://creativecommons.org/licenses/by/3.0/). 